\title{
Masculinity and Nation: A study of Gandhi and Savarkar
}

\author{
Rashmi Gopi \\ Department of Law, Vivekananda Institute of Professional Studies, Affiliated to Guru Gobind Singh \\ Indraprastha University, Delhi, India.
}

\begin{abstract}
This research paper focuses on how ideas of masculinity and nation are interlinked in the political thoughts of Mohandas Karamchand Gandhi and Vinayak Damodar Savarkar. To understand these aspects, the author has taken five significant areas to concentrate. They are the colonial context, education, religion, significant others and morality. The work emphasises the fact that masculinity is constructed, plural and fluid. Through the lives and thoughts of Gandhi and Savarkar we realize that experience and experiments with masculinity can change within a lifespan of a person. The same applies to the idea of nation. Both Gandhi and Savarkar envisioned the nation in terms of their understanding of masculinity. These ideas are relevant even today as the contemporary Indian politics plays with the very same ideas of Gandhi and Savarkar.

This research paper is a product of in depth study of original works of Gandhi and Savarkar. It also draws its strength from various theories on masculinity and nation. The author has taken constructivist approach, that is, to take both ideas of masculinity and nation as products of socio-cultural discourses of a particular context. The work explores how a particular hegemonic masculinity based on upper caste-upper class Hindu men in the colonial context influenced both Gandhi and Savarkar but their experiments with it were different.
\end{abstract}

Keywords: Gandhi, Masculinity, Nation, Savarkar

\section{Introduction}

The classical texts make it clear that the masculine individual is treated as universal, as representative and as everyman. The justification for this exercise is that man by nature has both power of reason and sense of justice, which are central to political life. Therefore women and children are being concluded by their husbands and fathers respectively (Pateman 1980) ${ }^{1]}$. If this is the case of classical texts then liberal theory and its critics fail to overtly justify why they favour the masculine individual. The masculine character of the individual remains unacknowledged and instead, the individual is implicitly presented as sexless (Pateman 1985) ${ }^{[2]}$. The feminist scholars exposed both gender chauvinism and gender blindness prevailing in different schools of thought. These works illuminated the role of women in politics by chronicling their participation and leadership and also uncovered the mechanisms of women's exclusion from political organizations, movements, decision making institutions and processes. These efforts 'to bring the women in' to the study of politics has often involved a conflation of the terms gender and women. Gender is not exclusively about women, it is about men, it is about many combinations between them and beyond them. While the emphasis on women by feminist scholars has begun to fill a critical gap in the study of politics, I felt an urge to explore a less travelled path, that is, to problematise the monolithic political category of men.

The problematisation of the 'men' began with the arrival of masculinity studies in 1970's. Before that there was no shortage of writings on men, as we said before, but they took masculinity as natural and monolithic. Books on men were many but books explicitly on men were few (Morgan 1992) ${ }^{[3]}$. Then what aroused interest in studying men and masculinities? Three major developments have generated this interest. The primary push has come from the particular historical combination of feminist studies with feminist politics, carrying in the theory of marginal, subaltern genders that produced gay and lesbian studies. This path broke with the presupposition of masculinity as a given structure of power, proposing 'powerless masculinities' as decisive for knowing the gendered world. The second impetus has been the discourse around HIV/AIDS. The questions that arose from the patterns of the spread of the disease among all-male groups instigated researchers to interrogate their assumptions of heterosexuality as an intelligible orientation that defined and fixed male sexuality. The third thrust can be located in the relation between academics and activists while academicians uncovered subalternity of the female gender, activists and policy makers tried to redress this subalternity. Arranging empowerment and reducing powerlessness made it clear that gender sensitive policy cannot exclude the involvement of men from the strategies of empowering women. How men's inclusion is to be encouraged requires a better understanding of how men view themselves, in relation with women and in relation with other men (Chopra et al. 2000) $)^{[4]}$.

This interest in studying the political category of 'men', the questions and answers related to what is masculinity, how it is formed led to evolution of different schools of thought. Some schools of thought take 
masculinity as natural, universal and fixed ${ }^{[i]}$ whereas others take it as constructed, context based and fluid. This paper takes the stand that masculinity is constructed. It is product of socio-cultural discourses. With changing contexts, the way masculinity is constructed differs and thus there is no single masculinity but masculinities. As masculinities are constructed and context based, at a given time and place certain masculinities attain more acceptance in society. The variations within masculinity leads to hierarchisation between masculinities. R.W. Connell introduced the concept of hegemonic masculinity in 1983 and in so doing firmly placed masculinity within power politics of gender. ${ }^{[i i]}$ Hegemonic masculinity provides a conceptual tool for examining how other relations of power and authority - racial, colonial, economic, geographic and international - may also be expressed in terms of sexual identity, including antagonistic or subordinate versions of masculinity (Dudink et al. 2004) ${ }^{[5]}$.

In Gramsci's usage 'hegemony' is not dominance through a special organization of force. For him hegemony is about creating consent for a certain social order through a web of institutions, social relations and ideas. A fully extended hegemony must rest on active consent, on a collective will in which various groups in society unite. Hegemony provides a more coherent and systematic world view which not only influences the mass of population but serves as a principle of organization of social institutions (Bottomore 1983) ${ }^{[6]}$. Hegemony acts as yardstick to measure what is right and proper. It becomes part of conscious thought by which most people in society order their perceptions of reality.

Applied to the sphere of gender relations, hegemony denoted the unequal social relations which empower certain groups of men and their model of masculinity to be the only way of being a man, such that there appears to be no other way of being a man. Hegemonic masculinity thus not only stratifies public life but also private life. The successful maintenance of hegemonic masculinity clearly depends, as Connell puts it, on the ability to impose a definition of the situation, to set the terms in which events are understood and issues discussed, to formulate ideals and define morality (Connell 1995) ${ }^{[7]}$.

The objectives of this paper are to explore how masculinities of Gandhi and Sawarkar were shaped under the condition of colonialism, where their masculinities lie in the hierarchy of masculinities, what are the points of convergence and divergence between them and finally how their ideas about masculinity influenced their ideas about India as a nation. Consequently, to have a better understanding of ideas of Gandhi and Savarkar this paper takes five points of reference: the colonial context, the role of education, the influence of significant others, the impact of morality and the role of religion. These points are not isolated but interlinked and had a combined impact on both Gandhi and Savarkar.

\section{Colonial Context}

Gandhi escaped colonization of mind under British rule. Gandhi had the intense intelligence to see hollowness of projected monolithic masculinity of West and East, that is, West's masculinity as matured, aggressive, civilized as against East's masculinity as childish, passive and barbarous. He rejected binary opposition between West and East (Nandy 1983) ${ }^{[8]}$. Thus he broke the back of the basic justification for colonialism, i.e., civilizing mission of superior-matured men of West over inferior-childish men of East. Gandhi further pushed this argument to conclude that development of an alternative masculinity is possible which is based on fluidity between, rather than opposition between, West and East, Public and Private, Masculinity and Femininity.

Gandhi's masculinity took qualities from both West and East. West's emphasis on punctuality, selfcontrol and sexual distance/abstinence influenced Gandhi's idea of masculinity. East's way of clothing (Khadi wearing), vegetarianism, spirituality, religion to be both private and public identity of a person and emphasis on non-violence shaped Gandhi's idea of masculinity.

Gandhi's idea of masculinity acknowledged presence of all in public discourse irrespective of gender, caste, class, region and religion as witnessed in his advocacy for equal voting and legal status for all. But his support for presence does not mean equal allocation of power to all. When it came to active participation and exercising of power he clearly counted a particular set of men and masculinities over other men and women. This point could be substantiated by the fact that Gandhi supported women's participation in national movement where their public roles were complementary to their household role. Gandhi sought to restrict women's participation to mass picketing of drink and drug shops, as to him this was an issue ideally suited to women, not only because they suffered from their husband's patronage of such shops, but also because the issue was one of purity and morality in personal life. Salt, however was an issue symbolizing the economic hardship Indians suffered under British rule, as such, it was an issue relating to public life and not therefore suitable for women to take up. The emphasis on the need for and virtue of, purity and suffering were central to Gandhi's thought (Kumar 1993) ${ }^{[9]}$. Here we can see Gandhi's vision supported "feminine masculinity" but not "masculinized femininity". Similarly Gandhi encouraged upper castes to treat untouchables as equals but simultaneously supported existence of established varna system based on different occupations. Gandhi told untouchables to see their work as respectable instead of advocating alternative occupations to them (Gandhi 1927) ${ }^{[10]}$. Gandhi's 
obsession with men to be breadwinners of the family, fidelity in marriage as an institution, vegetarianism and non-violence clearly reflects Gandhi's upper caste masculinity. This distanced and alienated lower castes and tribals from national movement led by Gandhi for their way of life is more open to women as equal partners in earning bread, open to relationships outside marriage and is based on so called violent occupations for upper castes like hunting and tanning (Illiah 1996) ${ }^{[11]}$. Thus Gandhi accepted plurality in society but with hierarchy between them.

It is true that Gandhi allocated and advocated power to few. But it should be acknowledged that the "power" by Gandhi was seen as a tool to help others rather than as a tool for exploitation. It was "power to", not "power over". He wanted to establish a relationship based on love force between various masculinities rather than on hate force. This is reflected in his support for trusteeship theory and Hindu-Muslim unity.

Unlike Gandhi, Savarkar was victim of colonization of mind under British rule. Savarkar unknowingly spoke the language of the colonizer (Nandy 1983) $)^{[12]}$. Savarkar interpreted India in the language of the colonizer. For example, he believed that there exists a binary opposition between matured militarized masculinity of West and childish feminine masculinity of East. Similarly Savarkar believed in the supremacy of fair skinned men. This is evident from his idea of fair skinned Aryans civilizing aboriginal tribes. He refused to see the 'Hindu' as dark skinned. Thus he refused 'Mohemmedenised Persian' meaning of Hindu as black $\left(\right.$ Savarkar 1923) ${ }^{[13]}$. Savarkar was also victim of 'number anxiety' created by British through census. The British aim of conducting and interpreting census in India was to divide Indians on the basis of caste, religion and region. Savarkar accepted the value attached to the census by the British and tried to build a monolithic image of the Hindu ${ }^{[i i i]}$ which was used to highlight difference and supremacy of the Hindus against the Muslims.

We have seen Gandhi accepted plurality in society. But Savarkar strived for homogenization of society. This was based on his belief that 'self' is always in opposition to the 'others'. Therefore total annihilation of the 'other' is a must for a strong nation of the 'self'. Savarkar followed two simultaneous processes in defining relationship between the 'self' and the 'other', that is, hierarchization and emulation (Jaffrelot 1996) ${ }^{[14]}$. Hierarchization was the process of connecting the foreign with what is one's own by way of subordination. Savarkar launched cultural reorganization in reaction to external threats real or/and imagined, in the form of conversion by Christian missionaries backed by the colonial British state in India, the socioeconomic political impact of British rule as a whole on India and the militancy of the Muslim minority. It involved 'defensive stigmatization of the other'. This means to brand the 'other' as disgraceful thus justifying the fight against the 'other'. For example, Savarkar projected Muslims as fanatical, diabolic and ruthlessly destructive to justify the fight against the Muslims (the 'other') by the Hindus (the 'self'). The 'emulation of the other' means 'self' to imitate those features of 'other' which make them powerful (Jaffrelot 1996) ${ }^{[15]}$. For this purpose Savarkar saw the Golden vedic age of Hinduism as an ancient version of the modern West. Savarkar reclaimed militarized masculinity of Hindus in the Golden Vedic age to fight against the British and Muslims ('other'). Savarkar's fixation with homogenization is reflected in his statement "Hinduise all politics, militarize Hinduism" (Savarkar 1967) $)^{[16]}$.

In reality Savarkar's effort in 'homogenization of Hindus' was 'Sanskritization of Hindus'. The idea of ideal masculinity was always Upper Caste Hindu masculinity. For this he tried to sanskritize Dalit and Adivasi social customs and worship patterns. To be Hindus, Dalits and Adivasis had to replace their local gods and goddesses with Ram, they had to stop cow slaughter for making leather and other products and they had to accept caste system and fairness of Manusmiriti (Teltumbe 2005) ${ }^{[17]}$. Savarkar wanted Dalits and Adivasis to serve as Hindutva foot soldier. Savarkar wooed Dalits and Adivasis to expand electoral constituency and to preempt a large unity of all sections of the oppressed people. In his assimilative unity amongst Hindus, BrahminKshatriya values crushed Dalit-Adivasi values. Savarkar in homogenising Hindus even ignored Jains, Buddhists and Sikhs fierce contention with Brahmanical Hinduism and tried to negate their separate religious identity as non-Hindus (Teltumbe 2005) ${ }^{[18]}$. Buddhist emphasis on values like love, equality, toleration, universalism and non-violence were seen as threat by Savarkar to Hindu militarized masculinity and Hindu nation.

\section{Role of Education}

Gandhi himself was an average student who was uncomfortable with British School's emphasis on oppressive, adventurous, violent, heterosexual masculinity of West and obedient (non-questioning of authority) and passive masculinity of East. Gandhi was not ready to accept British education's purpose as civilizing barbarous and childish Indian men. Thus when he became politically active one of his priorities was to find an alternative system of education for Indians. Gandhi's answer to this reflected in his book 'Nai Talim'. Gandhi affirmed the role of education in moulding masculinity. His idea of masculinity was not limited to physical but to mental, moral and spiritual levels also and his method of education targetted all these aspects in moulding masculinity.

Gandhi wanted Indian boys to combine iron will of militarized men with love force of women. Gandhi believed that schools should act as preparatory ground to develop love for indigenous culture. He regarded 
character building as the basic foundation of education (Gandhi 1927) ${ }^{[19]}$. Gandhi put high importance to role of the teacher in shaping masculinity. Gandhi believed it was teacher's responsibility to develop love for celibacy, truth, non-violence and vegetarianism amongst boys. Schools were seen by Gandhi as ground for establishing love force between diversities based on caste, religion and region (Gandhi 1953) ${ }^{[20]}$. Thus enabling boys to accept cooperation between diverse masculinities, not conflict.

Gandhi advocated supremacy of 'feminine masculinity', not 'masculinized femininity', femininity and masculinity in itself. Gandhi designed different programs of education for boys and girls. Boys' education focussed on outward activities and girls' on domestic affairs (Gandhi 1953) ${ }^{[21]}$. Gandhi supported boys to imbibe selected feminine qualities like patience, sacrifice and suffering to strengthen their masculinity, not to evade it. Gandhi made boys to learn cooking, cleaning and spinning but did not permit girls to learn activities that had to do with the public. For Gandhi public zone was men's zone.

Unlike Gandhi, Savarkar himself was an exceptionally good student. His anti-Non Hindu orientation found its root in school days itself. ${ }^{[\mathrm{iv}]}$ During his school life Savarkar was particular about success in examinations, had intense interest in reading, debating and physical training. At the age of fifteen he took a vow in front of Goddess Durga to strive nobly and sacrificing his nearest and dearest, his life and all, to fulfill the incomplete mission of revolutionaries to attain Indian freedom. He vowed to drive out the British from his beloved Motherland and to make her free and great once again (Keer 1966) ${ }^{[22]}$. The foundations of both his revolutionary nationalism and Hindu nationalism could be traced back to this period. In the year 1899 he formed a secret society named Patriot's Group (Keer 1966) ${ }^{[23]}$.

Like his political belief, Savarkar's idea of education was based on exclusion of non-Hindus. He believed in schools military training should be given to Hindu boys as it was necessary to protect honour of the women and nation. He was also clear about the fact that Muslim men should be kept out of defense forces because their loyalty to religion is higher than loyalty to nation (Savarkar 1970) ${ }^{[24]}$.

Savarkar believed to increase love for one's nation subjects like politics, history and economics are important. He taught these subjects to his co-prisoners in Andaman jail also (Savarkar 1950) ${ }^{[25]}$.

Savarkar indicated that it was duty of the education system to redeem lost glory of Hindu civilization and culture. For this purpose he wanted Hindi written in Devnagari script to be the national language of Hindus and himself engaged in purification of Sanskrit. He wanted schooling to impart in Hindu boys faith in energy and endurance and not in enjoyment (Keer 1966) ${ }^{[26]}$. He also wanted schools to be centres to fight against foreign goods and untouchability (Savarkar 1970) ${ }^{[27]}$. Savarkar also believed that to construct aggressive, adventurous, courageous Hindus masculinity Hindu have to reject ban imposed on them in the name of religion like banning of inter-caste, inter-religious sharing of water and food; inter-caste marriage; untouchability; reconversion of forced Hindu converts and travelling/ crossing of seas. Savarkar never had elaborate plans on girl's education as he firmly believed their role is limited to kitchen and child care. Savarkar only saw women as objects to filfil men's wishes, not as agents with their own drive to do things. Women had no active role in public and private spheres.

\section{Significant Others}

Gandhi saw fluidity between public and private lives. Therefore he talked about these spheres and his experiments in these spheres openly in his works.

Gandhi was influenced by his grandfather Ota Gandhi's organising ability and absolute integrity of character (Keer 1973) ${ }^{[28]}$. Gandhi admired the care with which his father balanced act between being a householder and a renouncer. ${ }^{[\mathrm{v}]}$

Gandhi appreciated shades of masculinity in his father like stubbornness, incorruptible character, tolerance, boundless energy, fearless independence from all kinds of domination and iron will. Gandhi's respect for his father did not blind him to his father's weaknesses. He wanted to outdo his father in social service, controlling temperament and carnal desires (Erikson 1969) ${ }^{[29]}$.

Gandhi had close intimacy with his school friend Sheikh Mehtab. Gandhi admired Sheikh Mehtab's physical strength which he always aspired to attain (Gandhi 1927) ${ }^{[30]}$. Sudhir Kakar rightly points out: "Sheikh Mehtab provided Gandhi with the adolescent refuge where young men can be both dismissive and fearful of women and heterosexual love, where in the vague homoeroticism of masculine banter and ceaseless activity a youth can gradually come to terms with the femininity within and without him" (Kakar 1996) ${ }^{[31]}$. Mehtab reflected all that which Gandhi considered evil like-meat eating, visiting brothels, smoking, stealing, even thinking of committing suicide. Still Gandhi clung to Mehtab to test somewhere down the line these evils hidden in himself. But Gandhi's success to rise above these evils and his failure to reform Mehtab taught Gandhi that a reformer cannot afford to have close intimacy with him whom he seeks to reform (Gandhi $1927)^{[32]}$. Thus Gandhi believed masculinity should have capacity for inner separation from all ties.

Gandhi exhorted his sons to be truthful like Prahlad but repeatedly threatened to disavow and to disown them when their truth meant rebellion against Gandhi (Erikson 1969) ${ }^{[33]}$. For example in 1926 Gandhi opposed 
Manilal's, his youngest son's, desire to marry Fatima, a Muslim girl. Gandhi preached Hindu-Muslim heart unity but opposed his own son's desire to take a step in that direction. Gandhi advised Manilal to follow three virtues - truth, non-violence and celibacy (Keer 1973) ${ }^{[34]}$. Gandhi imposed his idea of ideal masculinity on his sons through his way of diet, dressing and education. Thus Kasturba was right when she said Gandhi wanted his sons to be holy men before they are men (Erickson 1969) ${ }^{[35]}$. Gandhi kept intact patriarchy by playing the role of old patriarch with utmost zeal. As head of the family he always wanted his wife and sons to obey him without questioning. The idea that woman can be head of the family never had place in Gandhi's mind.

Gandhi said, "The outstanding impression my mother has left on my memory is that of saintliness" (Gandhi 1927) ${ }^{[36]}$. Importance attached to saintliness in Gandhi's picture of 'feminine masculinity' draws its origin from his mother, Putlibai. Gandhi's masculinity reflected feminine qualities of his mother like-early to rise, early to bed, fasting, religiosity, capacity to share. Gandhi was influenced by Putlibai's firm will to observe vows. But Gandhi twisted his vow to serve his interests ${ }^{[\mathrm{vi}]}(\text { Keer, 1973) })^{[37]}$.

Gandhi criticized excessive subjugation of women by husband but accepted subjugation of wife by husband per se. As said earlier Gandhi saw nothing wrong with husband's role as decision maker of the house. Gandhi always spoke about how Kasturba needed him. He never openly acknowledged his need for Kasturba (Erikson 1969) ${ }^{[38]}$. Gandhi saw women in two extremes - either as whore or as wife. He always assumed wives rarely have any sexual desires and thus sexual abstinence is easier for them to follow. He assumed the same about Kasturba. Gandhi paid little attention to how his experiments - usurption of motherhood, vegetarianism, sexual abstinence with wife, alternate methods of healing, simple living-affected Kasturba. Gandhi practised a kind of inner violence on those under his charge (Kishwar 1986) ${ }^{[39]}$.

Gandhi opened public space to women's presence during national movement. He inspired women to come out to public space by appealing them to become Sita (symbol of Swadeshi) and Draupadi (symbol of independence) (Kishwar 1986) ${ }^{[40]}$. Gandhi stressed the superiority of woman's suffering and self sacrifice rather than aggressive assertion and forceful intervention to protect their interests and to gain political power (Kishwar $1986)^{[4]}$. This clearly shows Gandhi never accepted 'masculinized femininity'. Gandhi believed the care of the children and the upkeep of the household are quite enough to fully engage wife's energy in Independent India. As this will simplify determining the varna of the children as husband's occupation will determine children's varna. Gandhi wanted women to be the queens of household and not wander in the streets or slave away in factories (Gandhi 1938) ${ }^{42}$. Streets and factories were seen by Gandhi as men's sphere. Gandhi expected men in public sphere to respect women and her chastity. The element of chivalry was an important ingredient of Gandhi's 'feminine masculinity'.

In the political field Gandhi understood importance of both prayer and purse. Thus he befriended both spiritual men like Raychand and Shraddhanand and richmen like Ambalal, Birla, Tata. This reflects Gandhi's picture of ideal masculinity to be combination of spiritualism and materialism. Gandhi measured masculinity with self control. He supported the concept "sex for procreation" and not the concept "sex for pleasure". Gandhi said the couple who realize that education of the child begins with conception will never have sexual union for the fulfillment of their lust, but only when they desire progeny (Gandhi 1927) ${ }^{[43]}$

Gandhi refused to give up his role as patriarch not only within his family but also in his ashram and the congress. To make decisions without taking his colleagues into confidence was Gandhi's significant trait which he developed into a political style (Keer 1973) ${ }^{[44]}$. Cancellation of non-cooperation movement in 1922 and imposing his choice of candidate as the President of the Congress even when be kept himself away from it in 1939 are a few examples to substantiate it.

On the other hand Savarkar strictly believed in the separation of public life from private life. He never felt to discuss his private life in depth in his works. Therefore there is great difficulty in constructing Savarkar's equations with his wife and children. From his writings it is clear that heroes in his life were confined to upper caste Hindu men like - Shivaji, Mangal Pandey, Nana Sahib and Tatia Tope. Savarkar admired their 'aggressive masculinity'. He wanted masculinity to be adventurous, fearless, brave-bold, civilized, valourous, industrious, enterprising, chivalrous and sexually self controlled. For the same reason he admired revolutionaries in freedom struggle from Abhinav Bharat to Indian National Army (Savarkar 1967) ${ }^{[45]}$. For Savarkar males are the essential community agents, regardless of the community in question (Jaffrelot 2005) ${ }^{[46]}$. He equated masculine features of communities to determine relative strength of the nation. The feminine is a space for males to realize their self-identity (Jaffrelot 2005) ${ }^{[47]}$. Masculinity is measured in terms of men's ability to protect feminine (both at individiaul and national levels).

Savarkar worshipped leaders who lead from the front in times of crisis but in his own life he preferred to lead from behind. He instigated others to murder but he himself never held the gun. He goaded the assassin but covered his own tracks skillfully ${ }^{[\mathrm{vii}]}$ (Noorani 2002) ${ }^{[48]}$.

Savarkar valued fraternal bonding. He saw his elder broth Ganesh as his father and treated younger brother Narayan as his son. However he failed to create fraternal bonding with his Hindu Mahasabha colleagues. The long isolated revolutionary and prison life he led made him distrustful of and aloof from the 
society. For example, Savarkar refused to meet visitors, even his party colleagues, without prior appointment. Moody and erratic, he could not create certain warmth that was needed in a party chief (Keer 1966) ${ }^{[49]}$.

Savarkar observed women only as relational subjects, that is, as a mother, sister, wife or daughter and not as independent subjects. Savarkar had a microscopic opinion of women; that is, limited to women's reproductive and rearing roles. Savarkar expected women to reproduce sons for the nation and women should inspire their husbands and sons to sacrifice lives for the defense of the nation. Savarkar associated Bharatmata with a chaste female body where her femininity is preserved by the hegemonic masculinity of her male subjects. He always placed masculinity above femininity and counted only militaristic-heterosexual men as masculine. For Savarkar to see women independent of their sexuality in public sphere was difficult. Even while discussing Rani of Jhansi's role in the first war of Indian independence in 1857, Savarkar painted a picture where the Rani for a moment, had the fear of sexual assault on battlefield (Savarkar 1970) ${ }^{[50]}$. Here we can see Savarkar's thinking conforming with the heterosexual masculine view that only women are subjected to sexual torture in battlefield and they lack the endurance power to deal with it.

Savarkar in his personal life admired sister-in-law Yashodabai for being a symbol of suffering and devotion with sublime courage of sati. Savarkar never mentioned any challenges to his authority at home either by his wife or children. As mentioned earlier his relation with them are not mentioned in depth in any of his writings.

\section{Role of religion}

Gandhi counted religion to be the basis of masculinity but never accepted any particular religion's masculinity to have sole claim over India as a nation. Gandhi felt religion shaped 'being a man'. In his book To the communal harmony he described Sikhs as brave, Muslims as aggressive and Hindus as non-violent (Gandhi $1963)^{[51]}$.

Gandhi emphasised role of religion in defining masculinity but one has to keep in mind that he stood for unorganised religion (Nandy 1983) (52] $^{[52}$ Gandhi believed in reality there are as many religions as there are individuals, but those who are conscious of the spirit of nationality do not interfere with one another's religion. If they do, they are not fit to be considered a nation (Gandhi 1938) ${ }^{[53]}$. Gandhi believed aim of all religion is self-control in thought, word and deed. Renunciation of pleasure is the highest form of religion which in turn improves inner quality of soul (Keer 1973) ${ }^{[54]}$. Thus for Gandhi degree of masculinity could be measured by success rate of progressive reduction of wants by men in terms of food, property and sex.

For communal harmony Gandhi advocated 'mutual generosity' to be an ingredient of masculinities in both Hindus and Muslims. But critics like Keer feel that Gandhi's 'mutual generosity' always remained onesided. Gandhi never asked the Muslims to concede anything to the Hindus. Thus majority (Hindus) giving concessions to minority made 'non Hindus' to view India as a 'too Hindu nation' where minority is at the mercy of majority and Hindus felt India as a 'not Hindu enough' nation where they have to constantly give in to minorities (Keer 1973) ${ }^{[55]}$.

Savarkar believed religion is the basis for both masculinity and nation. His vision of India as a nation had place only for Hindu masculinity. Savarkar based his idea of masculinity on Hindutva, not Hinduism. ${ }^{\text {[vii] }}$ Hindu masculinity of Savarkar was based on valour of arms, purity of aims and sublimity of souls (Savarkar $1923)^{[56]}$. Savarkar made difference between Hindutva and Hinduism in his book Hindutva: Who is a Hindu. But a closer look makes it clear that Hindutva heavily draws its root from the upper caste Hinduism. For example Savarkar thought the peculiar mark of Hindu nation is four varnas, valued Sanskrit as the language of the Hindu, used Ram as the God of the Hindu. At the same time Savarkar was critical of some aspects of Hinduism like condemnation of use of force, ban on reconversion, lack of organization for a common defence of Hindu faith, belief in decentralizing institutions and superstitions (Savarkar 1942) ${ }^{[57]}$. Thus Savarkar wanted Hindu masculinity to be devoid of these evils of Hinduism, that is, Hindu masculinity to be militarized, organised and centralized. For this purpose, we have mentioned earlier, how Savarkar concealed divisions within Hindu men in terms of caste, creed, language or region. Similarly he concealed socio-economic and political similarity of the Muslims to the lower caste Hindi men (Aloysius 1994) ${ }^{[58]}$. Savarkar built monolithic Hindu masculinity always in opposition to 'threatening others' (both British and Muslims).

\section{Role of morality}

For Gandhi role of morality begins with individual as the centre and is interconnected to higher levels like community, district, province, nation and world. Gandhi, as we have seen earlier, believed in plurality of truth. Therefore he advocates relationship between 'hegemonic masculinity' and 'subordinate masculinity' to be based on cooperation and care.

Gandhi emphasized the fact that one should dislike the wrong, never the wrong doer. Therefore prison's should be place for reforming wrong doers, not punishing them. An indispensable element in Gandhi's idea of masculinity is love force and patience to reform the wrong-doer. 
Gandhi saw the 'other' as an extension of the 'self'. He believed understanding of 'self' leads to better understanding of 'other'. That is the reason why he argued for self introspection by each individual as crucial for communal harmony (Gandhi 1963) ${ }^{[59]}$.

For Gandhi morality meant to attain mastery over passions and to have active struggle against injustices and oppressions. Gandhi believed if each individual followed this then there is need for community vigilance and minimum militarization of nation.

Gandhi had high standards of morality to be followed by women. He believed sons and husbands would stop killing people if women cease to take delight in such acts of men (Gandhi 1946) ${ }^{[60]}$. Similarly he believed women should stay away from becoming prostitutes. He equated women prostitutes with thieves as they stole virtue. But Gandhi was not equally critical about better known exploiters of society like landlords and corrupt businessmen, whose money he needed to carry out his experiments (Kishwar 1986) ${ }^{[61]}$. This shows Gandhi's reluctance to find fault with men for social evils. Thus in the ultimate analysis it seems Gandhi remained at some levels within the framework of 'hegemonic masculinity'.

Savarkar's idea of morality was based on binary opposition between 'self' and 'other'. He clearly demarcated boundaries between 'self' and 'other'. He visualized relation between the two be based on fear and force. He believed that individuality and independence of the 'self' is maintained only when there is an opposite 'other'. Savarkar signified that in the conflict between 'self' and 'other', the masculinity of 'self' is strong if it is ready to bear and endure most forms of physical and mental torture.

Like Gandhi, Savarkar favoured reforms in jail. Savarkar opposed conversion of Hindu prisoners to Islam or Christianity. He believed criminality is not hereditary. Therefore if Hindu prisoner's are converted, Hindu lose future generations to those other religions. To prevent this temptation to conversion, prison should have provision for clean air, clean water and work to engage them mentally and physically.

Savarkar placed first duty of Hindu men as self preservation and self defence. He praised Hindu men's inherent capacity of resurrection, of renaissance and of rejuvenation.

Savarkar tried to find a balance between individual and nation. It was individual's clearing of requisites of Hindutva as fatherland, holyland, common culture and civilization which tied him to nation as individual's character is reflected in nation. But Savarkar wanted to check individualism as such which threatens public good. Only individualism which promotes nation's wealth, intellect, fame and independence is acceptable to Savarkar. Here we could sense Savarkar's support for majority Hindu's individualism and suppression of minority's individualism. And further he supports constitution by the majority.

For Savarkar there existed only one truth - truth of, truth by, truth for Hindu. Thus in his idea of masculinity there is only one ideal masculinity, that is, masculinity of Hindu. India as a nation is Hindu nation. He believed that only Hindu men's 'holyland' and 'fatherland' are rooted in the territory of India. Thus Hindu masculinity has sole claim over India's nationhood.

\section{Conclusion}

The author has illuminated various points of convergence and divergence in the ideas of Gandhi and Savarkar. Both of them were influenced by their vantage point as North Indian upper caste men. This is apparent in how both of them emphasised use of Hindi as national language.They failed to see that for people belonging to the non-Hindi belt, learning Hindi is as alien and as difficult as learning English. Similarly, both of them talked about reforming the caste system but not about ending it. Gandhi and Savarkar opposed untouchability but supported the very root cause of untouchability, that is, varnashrama dharma. Likewise, both of them justified division of labour between men and women, that is, private sphere as women's sphere and public sphere as men's domain. Gandhi subscribed to the idea that women's role in public sphere is only for nationalist movement. He believed once India attains independence women should limit themselves to private sphere. Even when he backed women's role in public domain it was based on essentialising supposedly feminine qualities like non-violence, care and capacity to endure sufferings. Gandhi supported feminine-masculinity but never endorsed masculine-femininity. On the part of Savarkar, he never acknowledged women's role as independent agents in public sphere. Thus the underlying assumption for both of them was that women are different from men and women have to be always under the guidance of men.

Yet there are stark points of divergence between Gandhi and Savarkar. The meanings of masculinity and nation changed for both Gandhi and Savarkar within their lifespan. Gandhi who was an introvert in his early youth completely transformed himself into a vocal and confident public man. Gandhi in his youth looked up to British way of being a man. This was evident in his experiments with diet and dress. But later he realized the futility of imitating British aggressive masculinity. Young Gandhi was uncomfortable with his sexuality as he believed he lacked the physical build of an aggressive, heterosexual man. Later he accepted his femininemasculinity based on non-aggression and non-violence and propagated it to be followed by other men. On the other hand, Savarkar who was active and vocal in politics during his early youth turned out to be a suspicious and secluded man in his later life. Initially Savarkar saw the British as the primary enemy of India and their 
expulsion from India was his primary motive. But later for him, the primary enemy of India became the Muslims.

In this paper, it is also highlighted that Gandhi escaped colonization of mind in understanding both masculinity and nation as he opposed predominant view of the British based on aggressive-heterosexual masculinity and aggressive-homogeneous nation. Savarkar's ideas conformed with the predominant British viewpoints. Thus, within the same context of India under colonialism, Gandhi and Savarkar picked up very different understandings of masculinity and nation.

Gandhi's ideas of masculinity and nation were based on non-violence and plurality of truth. He saw the 'other' as an extension of the 'self'. This made him to develop non-violent approach towards the 'other'. He was never for organised Hinduism. His Ram was compassionate, epitome of justice and love. His religion accepted plurality within and outside Hinduism. Gandhi, unlike Savarkar, never counted religion as a criterion to permit or deny membership to India as a nation. Thus his ideas of masculinity and nation were inclusive and plural.

Gandhi's idea of nation was a combination of supposed feminine and masculine qualities of compassion, non-violence, endurance, firmness, self-control, questioning mind. He never compartmentalized private and public lives. His experiments in dress, sex, diet, all had political implications. Contrary to this, Savarkar's ideas of masculinity and nation were based on militarization and homogenization. He saw the 'other' as opposite to the 'self' and assumed a convergence and cooperation between the two as impossible. In his overenthusiasm to homogenize masculinity and nation, Savarkar was intolerant towards plurality within and outside Hinduism. Savarkar never put light on his personal relationship with his wife and children. All his writings are silent about his family life. This forces us to assume that Savarkar made the conventionally clear division between private and public spheres of life, wherein private had no impact on public life. Likewise in his idea of the nation men are the representatives of their communities. His idea of masculinity and nation deny independent agency to the women.

By focusing on Gandhi and Savarkar, the author has attempted to illuminate multiple ways in which meanings of masculinity and nation were constructed and performed in India under colonialism. This helps us to understand how the ideal male citizen of post independent India has been an inheritor of this legacy.

\section{Endnotes}

[i] Masculinity as fixed and singular has been supported by socio-biologists like Edward Wilson and Role theorists like Lewis Terman and Catherine Miles.

[ii] R. W. Connell introduced the term 'Hegemonic Masculinity' to highlight power politics within masculinity, thus puncturing monolithic picture of masculinity. R. W. Connell prefers to address oneself as 'itself' to move beyond the binaries of femininity and masculinity.

[iii] Savarkar accepted the value attached to the census conducted by the British. Savarkar tried to build a monolithic image of the Hindu through census, in which Jains, Arya Samajists, Sikhs and Lingayats were counted as integral part of Hinduism. Savarkar's fixation with homogenization is reflected even in his statement 'Hinduise all politics, militarize Hinduism'.

[iv] Savarkar's anti-non Hindu approach was clear from his childhood when he led Hindu schoolmates to stone a local village mosque in the background of Hindu-Muslim riots in United Province in the year 1893.

[v] For predominant upper caste, upper class Hindus, the masculinity of householder and renouncer are seen as diametrically opposite as one explores power in family and other moves away from family and loved ones but attains other sense of power by evoking the ability to give up everything and getting closer to God.

[vi] Gandhi was influenced by his mother Putlibai's firm will to observe vows. But Gandhi twisted his vow to serve his interests. Gandhi observed vow to keep away from wine and meat in London when he went there to become a barrister. But he strayed when it came to observe the vow to keep away from women. In order to have friendship with girls, he pretended to be unmarried.

[vii] Savarkar goaded the assassin but covered his own tracks skillfully. This is evident in episodes like attack on life of William Curzon Wylie by Madanlal Dhingra in 1909, attack on Sir Ernest Hotson by V.G Gogate in 1931 assassination of Gandhi by Nathuram Godse in 1948.

[viii] Savarkar distinguished Hinduism and Hindutva. For him, Hinduism provided only spiritual-religious content. Hindutva drew its strength from Hindu civilization, from all the departments of thought and activity of Hindu race. Hindus are tied by common fatherland, blood, common culture and civilization, common heroes, common history and above all by the will to remain united. Hindutva of Savarkar is based on valour of arms, purity of aims and sublimity of souls. 


\section{References}

[1]. Pateman, C (1980), "Women and Consent”, Political Theory, Vol. 8, No. 2, (May), pp. 149-168.

[2]. Pateman, C (1985), The Problem of Political Obligation: A critique of Liberal Theory. Cambridge: Polity Press.

[3]. Morgan, David., (1992), Discovering Men. New York : Routledge

[4]. Chopra, R. Dasgupta, C. and Janeja, M., (2000). "Understanding Masculinity". Economic and Political Weekly. (May 6), pp 16071609.

[5]. Dudink, S. Hagemann, K. and Tosh, J. (eds.), (2004), Masculinities in Politics and War: Gendering Modern History. Manchester: Manchester University Press.

[6]. Bottomore, T. (1983), A Dictionary of Marxist Thought, Oxford: Blackwell Publishers.

[7]. Connell, R.W. (1995), Masculinities, Cambridge: Cambridge University Press.

[8]. Nandy, Ashis. (1983), The Intimate Enemy: Loss and Recovery of Self Under Colonialism, Delhi: OUP.

[9]. Kumar, Radha (1993), The History of Doing: An Illustrated Account of Movements for Women's Rights and Feminism in India, 1800-1990. New Delhi: Kali for Women.

[10]. Gandhi, M.K. (1927), The Story of my experiments with Truth. Ahmedabad: Navjiwan Publishing House.

[11]. Ilaiah, Kancha. (1996), Why I am not a Hindu: A Sudra Critique of Hindutva Philosophy, Culture and Political Economy, Calcutta: Stree-Samya Books.

[12]. Nandy, Ashis. (1983), The Intimate Enemy: Loss and Recovery of Self Under Colonialism, Delhi: OUP.

[13]. Savarkar, V.D (1923), Hindutva: Who is a Hindu?, New Delhi: Hindi Sahitya Sadan.

[14]. Jaffrelot, C. (1996), The Hindu Nationalist Movement and Indian Politics, New Delhi: Penguin Books India Ltd.

[15]. Jaffrelot, C. (1996), The Hindu Nationalist Movement and Indian Politics, New Delhi: Penguin Books India Ltd.

[16]. Savarkar, S.S and Joshi, G.M (eds.), (1967), Historic Statements of V.D Savarkar, Bombay: Popular Prakashan.

[17]. Teltumbe, A (ed.) (2005), Hindutva and Dalits: Perspectives for Understanding Communal Praxis, Kolkata: Samya.

[18]. Teltumbe, A (ed.) (2005), Hindutva and Dalits: Perspectives for Understanding Communal Praxis, Kolkata: Samya.

[19]. Gandhi, M.K. (1927), The Story of my experiments with Truth. Ahmedabad: Navjiwan Publishing House.

[20]. Gandhi, M.K. (1953), Towards New Education, Edited by Bharatan Kumarappa, Ahmedabad: Navjivan Publishing House.

[21]. Gandhi, M.K. (1953), Towards New Education, Edited by Bharatan Kumarappa, Ahmedabad: Navjivan Publishing House.

[22]. Keer, Dhananjay (1966), Veer Savarkar, Bombay: Popular Prakashan.

[23]. Keer, Dhananjay (1966), Veer Savarkar, Bombay: Popular Prakashan.

[24]. Savarkar, V.D (1970) The Indian War of Independence 1857, New Delhi: Rajdhani Granthagar.

[25]. Savarkar, V.D (1950), The Story of my Transportation for Life, Bombay: Sadbhakti Publications.

[26]. Keer, Dhananjay (1966), Veer Savarkar, Bombay: Popular Prakashan.

[27]. Savarkar, V.D (1970) The Indian War of Independence 1857, New Delhi: Rajdhani Granthagar.

[28]. Keer, Dhananjay (1973), Mahatma Gandhi: Political Saint and Unarmed Prophet. Bombay: Popular Prakashan.

[29]. Erikson, E.H. (1969), Gandhi's Truth, Toronto: W. W. Norton and Company Inc.

[30]. Gandhi, M.K. (1927), The Story of my experiments with Truth. Ahmedabad: Navjiwan Publishing House.

[31]. Kakar, S (1996), Intimate Relations, New Delhi: Penguin.

[32]. Gandhi, M.K. (1927), The Story of my experiments with Truth. Ahmedabad: Navjiwan Publishing House.

[33]. Erikson, E.H. (1969), Gandhi's Truth, Toronto: W. W. Norton and Company Inc.

[34]. Keer, Dhananjay (1973), Mahatma Gandhi: Political Saint and Unarmed Prophet. Bombay: Popular Prakashan.

[35]. Erikson, E.H. (1969), Gandhi's Truth, Toronto: W. W. Norton and Company Inc.

[36]. Gandhi, M.K. (1927), The Story of my experiments with Truth. Ahmedabad: Navjiwan Publishing House.

[37]. Keer, Dhananjay (1973), Mahatma Gandhi: Political Saint and Unarmed Prophet. Bombay: Popular Prakashan.

[38]. Erikson, E.H. (1969), Gandhi's Truth, Toronto: W. W. Norton and Company Inc.

[39]. Kishwar, Madhu (1986), Gandhi and Women, Delhi: Manushi Prakashan.

[40]. Kishwar, Madhu (1986), Gandhi and Women, Delhi: Manushi Prakashan.

[41]. Kishwar, Madhu (1986), Gandhi and Women, Delhi: Manushi Prakashan

[42]. Gandhi, M.K. (1938), Hind Swaraj, Ahmedabad: Navjivan Publishing House.

[43]. Gandhi, M.K. (1927), The Story of my experiments with Truth. Ahmedabad: Navjiwan Publishing House.

[44]. Keer, Dhananjay (1973), Mahatma Gandhi: Political Saint and Unarmed Prophet. Bombay: Popular Prakashan.

[45]. Savarkar, S.S and Joshi, G.M (eds.), (1967), Historic Statements of V.D Savarkar, Bombay: Popular Prakashan.

[46]. Jaffrelot, C (ed.) (2005), The Sangh Parivar: A reader, New Delhi: Oxford University Press.

[47]. Jaffrelot, C (ed.) (2005), The Sangh Parivar: A reader, New Delhi: Oxford University Press.

[48]. Noorani, A.G. (2002), Savarkar and Hindutva, New Delhi: Leftwood.

[49]. Keer, Dhananjay (1966), Veer Savarkar, Bombay: Popular Prakashan

[50]. Savarkar, V.D (1970) The Indian War of Independence 1857, New Delhi: Rajdhani Granthagar.

[51]. Gandhi, M.K. (1963), The way to communal harmony, Edited and compiled by U.R. Rao, Ahmedabad: Navjivan Publishing House

[52]. Nandy, Ashis. (1983), The Intimate Enemy: Loss and Recovery of Self Under Colonialism, Delhi: OUP.

[53]. Gandhi, M.K. (1938), Hind Swaraj, Ahmedabad: Navjivan Publishing House.

[54]. Keer, Dhananjay (1973), Mahatma Gandhi: Political Saint and Unarmed Prophet. Bombay: Popular Prakashan.

[55]. Keer, Dhananjay (1973), Mahatma Gandhi: Political Saint and Unarmed Prophet. Bombay: Popular Prakashan.

[56]. Savarkar, V.D (1923), Hindutva: Who is a Hindu?, New Delhi: Hindi Sahitya Sadan.

[57]. Savarkar, V.D (1962), Hindu Pad- Padshahi, Poona: Manohar Granth Mala.

[58]. Aloysius, G. (1994), "Trajectory of Hindutva”, Economic and Political Weekly, (June 11), pp. 1450-1452.

[59]. Gandhi, M.K. (1963), The way to communal harmony, Edited and compiled by U.R. Rao, Ahmedabad: Navjivan Publishing House.

[60]. Gandhi, M.K. (1953), Towards New Education, Edited by Bharatan Kumarappa, Ahmedabad: Navjivan Publishing House.

[61]. Kishwar, Madhu (1986), Gandhi and Women, Delhi: Manushi Prakashan. 